\title{
Cortical processing of pain
}

Citation for published version (APA):

Vossen, C. (2018). Cortical processing of pain: the role of habituation. [Doctoral Thesis, Maastricht University]. Datawyse / Universitaire Pers Maastricht. https://doi.org/10.26481/dis.20180627cv

Document status and date:

Published: 01/01/2018

DOI:

$10.26481 /$ dis.20180627cv

Document Version:

Publisher's PDF, also known as Version of record

\section{Please check the document version of this publication:}

- A submitted manuscript is the version of the article upon submission and before peer-review. There can be important differences between the submitted version and the official published version of record.

People interested in the research are advised to contact the author for the final version of the publication, or visit the DOI to the publisher's website.

- The final author version and the galley proof are versions of the publication after peer review.

- The final published version features the final layout of the paper including the volume, issue and page numbers.

Link to publication

\footnotetext{
General rights rights.

- You may freely distribute the URL identifying the publication in the public portal. please follow below link for the End User Agreement:

www.umlib.nl/taverne-license

Take down policy

If you believe that this document breaches copyright please contact us at:

repository@maastrichtuniversity.nl

providing details and we will investigate your claim.
}

Copyright and moral rights for the publications made accessible in the public portal are retained by the authors and/or other copyright owners and it is a condition of accessing publications that users recognise and abide by the legal requirements associated with these

- Users may download and print one copy of any publication from the public portal for the purpose of private study or research.

- You may not further distribute the material or use it for any profit-making activity or commercial gain

If the publication is distributed under the terms of Article $25 \mathrm{fa}$ of the Dutch Copyright Act, indicated by the "Taverne" license above, 


\section{Summary}

A painful event cannot be translated through a one-to-one relationship into a pain experience. A pain experience is influenced by many factors, such as genetics, cognition, attention, prior pain experience, and mood. Thus, pain is a multidimensional experience, and thus, wide variability exists between individuals.

Objective measurement of pain is a challenge. Compared with questionnaires, pain event-related potentials (pain-ERPs), brain potentials that are related to such events as painful stimuli, might be a more objective method of measuring pain. On administration of several stimuli, the corresponding brain potentials diminish, due to the phenomenon of habituation. Habituation is a mechanism that is believed to be involved in the chronification of pain and is impaired in many chronic pain populations. Habituation to pain has been proposed as a protective mechanism in the transition from acute to chronic pain.

The primary goal of this thesis was to examine the relationship between habituation and chronic pain. A secondary objective was to determine the function of pain hypervigilance-heightened attention to pain sensations-in habituation and chronic pain. Heightened attention to pain can increase the pain intensity report and as such may impair habituation. To these ends, an alternative method was developed to analyze event-related EEGs, called the event-related fixed-interval (ERFIA) multilevel method. This approach allows one to study not only peaks but the entire defined poststimulus period.

Chapter 1 introduces the phenomenon of pain and its multidimensional nature and interindividual variability. Then, the neurophysiological pathway from nociception to pain experience and several methods to measure pain are discussed. Finally, the research questions that constitute the backbone of this thesis are presented.

Chapter 2 provides a general background on the pain-ERP and its structure. Next, the factors that influence the pain-ERP, such as stimulus intensity, habituation, neuroticism, and gene polymorphisms, and the predictive value of the pain-ERP in clinical pain are discussed. The second part of this chapter deliberates on several methods and their methodological aspects in analyzing the pain-ERP. Peaks are important in the analysis of the ERP, but in theory, each latency point can contain meaningful information. Based on this idea, an alternative analysis method is introduced that combines small areas under the curve (AUCS) of the EEG with multilevel regression, a statistical analysis method, allowing the entire poststimulus epoch to be studied. With this method, ERP information can be examined at the single-trial level, thus enabling an analysis of the habitu- 
ation of a series of stimuli. At the end of this chapter, pilot results with regard to stimulus intensity, previous stimulus intensity, and habituation are discussed.

Chapter 3 elaborates further on the alternative analysis method. In this thesis, the proposed analysis method is called the event-related fixed-interval areas (ERFIA) multilevel method. The primary goal is to determine whether the ERFIA multilevel method renders similar results as conventional peak analysis. The ERFIA multilevel method is tested on an existing EEG dataset of 84 subjects who underwent a pain rating protocol of 150 electrical stimuli of 5 stimulus intensities. The period after the stimulus, the so-called epoch of $1500 \mathrm{~ms}$, was partitioned into areas of $20 \mathrm{~ms}$. The variance in ERP signal was examined by modeling consecutive 20-ms ERFIAs as dependents, explained by several variables, including stimulus intensity, previous stimulus intensity, and habituation (trial number). Not only did the ERFIA multilevel method generate similar results compared with peak-based analysis, it also demonstrated that the influences of stimulus intensity and ha-bituation could be observed over a much broader poststimulus range. In addition, our study detected a highly significant interaction between actual and previous stimulus intensity, persisting from 380 to 660 ms poststimulus. This finding implicates a process in which the brain makes a "comparison" with information on previous stimulus intensity, possibly reflecting stimulus-related memory processes.

Chapter 4 evaluates the differences in cortical processing of (non-)painful stimuli between chronic pain and pain-free subjects, with respect to intensity and habituation. Three forms of habituation are studied: a linear, inverse, and quadratic function of stimulus number. In this study, no differences in cortical processing of stimulus intensity were noted between the chronic pain and pain-free groups. However, subjects with chronic pain showed a decreased habituation in all three forms of habituation. At the cortical level, it appears that individuals with chronic low back pain acclimate to a series of painful and non-painful stimuli compared with pain-free subjects. Habituation to pain might be a key factor in the chronification of pain. However, testing this hypothesis requires longitudinal studies.

Chapter 5 studies the relationship between pain hypervigilance and habituation in the cortical processing of painful stimuli. Pain hypervigilance is defined as heightened attention to painful sensations. Pain hypervigilance may result in a higher pain intensity report. Hypervigilance can already be apparent in pain-free individuals and as such might be a predisposing factor in the onset of chronic pain disorders. This chapter examined whether hypervigilant healthy subjects displayed a disparate cortical processing of pain compared with non-hypervigilant healthy subjects. Also, the influence of hypervigilance on habituation was studied. The results show that pain hypervigilance directly influenced the pain-ERP from 440 to 580 ms poststimulus, independent of habituation. In addition, pain hypervigilance affected linear and quadratic habituation. Thus, pain hy- 
pervigilance impacts the cortical processing of painful stimuli, suggesting that pain hypervigilance modulates the pain experience through altered cortical habituation.

Chapter 6 analyzes whether pain hypervigilance further impairs habituation in chronic pain subjects. The relationship between pain status and habituation was not moderated by pain hypervigilance. Chronic pain status affected linear habituation and dishabituation (quadratic function) from 220 to $260 \mathrm{~ms}$ for nearly all electrodes and from 580 to $640 \mathrm{~ms}$ for frontal electrodes. The effect of pain hypervigilance on habituation was observed primarily from 480 to 820 ms poststimulus for right-side and central electrodes. Thus, pain hypervigilance and chronic pain independently influence habituation to painful stimuli-not synergistically. Further research is required to confirm that these effects are mediated by separate pathways.

Chapter 7 provides an overview and a general discussion of the studies that have been included in this thesis. The advantages of the ERFIA multilevel method versus peakbased methods are described. In addition, methodological considerations are discussed, and aspects for development and refinement of the multilevel method, and suggestions for future research are proposed. With the ERFIA multilevel analysis method, it was demonstrated that stimulus intensity, habituation, and the psychological factor pain hypervigilance had influence over broad poststimulus ranges of the pain-ERP. Replication of the present findings, however, is critical. A combination of the ERFIA multilevel analysis method with other modalities, such as MRI and ESM, will undoubtedly increase insights into the localization of pain processing and its time effects and context. 



\section{Samenvatting}

Een pijnlijke prikkel kan niet één op één vertaald worden naar een pijnervaring, omdat pijn een subjectieve ervaring is. De pijnervaring wordt onder andere beïnvloed door genetica, cognities, aandacht, vroegere pijnervaringen, stemming. Pijn is dus een multidimensionale ervaring, waardoor er een grote variatie tussen individuen bestaat. Dit alles maakt dat pijn moeilijk objectief te meten is.

In vergelijking tot vragenlijsten, worden Pijn 'Event-Related Potentials' (pijn-ERP) oftewel, hersenpotentialen gerelateerd aan een gebeurtenis, bijvoorbeeld een pijnprikkel, gezien als een meer objectieve maat om pijn te meten. Bij meerdere keren toedienen van een pijnprikkel treedt er gewenning op, ook wel habituatie genoemd, en de corresponderende pijnpotentialen worden kleiner. Habituatie aan pijn wordt gezien als een van de mechanismen die beschermend werken in de transitie van acute naar chronische pijn. Uit eerder onderzoek blijkt dat habituatie verminderd is in mensen met chronische pijn. Dit proefschrift onderzoekt de rol van habituatie in de corticale verwerking van pijn bij gezonde mensen en bij individuen met chronische pijn. Verhoogde aandacht voor pijn, zogenaamde pijn hypervigilantie, kan een pijnervaring versterken. Daarom wordt ook onderzocht of pijn hypervigilantie de habituatie van de corticale pijnverwerking remt en of er een verschil bestaat tussen gezonden en individuen met chronische pijn. Voor dit doeleinde werd een alternatieve methode ontwikkeld voor de analyse van Event-Related Potentials. Deze methode heet de Event-Related FixedInterval Areas (ERFIA) multilevel methode. Met deze methode kan men het hele ERP signaal analyseren en niet alleen de pieken.

Hoofdstuk 1 betreft een introductie in het fenomeen pijn. Het multidimensionale karakter en de variatie tussen individuen wordt besproken, als ook het neurofysiologische proces van pijnprikkel naar de corticale verwerking pijn. Daarnaast worden verschillende methoden om pijn te meten uiteen gezet, zoals vragenlijsten en neuro imaging technieken, waaronder het elektro-encefalogram (EEG). Tenslotte worden de onderzoeksvragen die de basis vormen voor dit proefschrift gepresenteerd.

Hoofdstuk 2 geeft algemene achtergrondinformatie over het pijn-ERP en de structuur van het ERP. Tevens worden factoren die van invloed zijn op het pijn-ERP beschreven, zoals de stimulusintensiteit, habituatie, neuroticisme en genpolymorfismen. Verder wordt de predictieve waarde van het pijn-ERP in relatie tot klinische pijn besproken. Het tweede gedeelte van hoofdstuk 2 gaat in op veel gebruikte analyse methoden voor het pijn-ERP en de methodologische aspecten hiervan. Niet alleen pieken van het pijn-ERP zijn van belang in de analyse, in theorie zou elk punt van het pijn potentiaal na een stimulus relevante informatie kunnen bevatten. Op basis van deze opvatting wordt een 
alternatieve methode geïntroduceerd die kleine oppervlaktes, zogenoemde 'areas under the curve' (AUCS) van het EEG, combineert met de multilevel regressie analyse, een statistische analyse methode. Door AUCs te gebruiken in plaats van pieken kan de gehele periode na een stimulus, 'de epoch', bestudeerd worden. Daarnaast kan op 'single trial' niveau, dus op het niveau van een individuele pijnprikkel, ERP informatie geanalyseerd worden en daardoor ook habituatie van een serie prikkels beter onderzocht worden. Aan het einde van dit hoofdstuk worden de eerste resultaten van een analyse met betrekking tot de invloed van stimulus intensiteit, de intensiteit van de voorgaande prikkel en habituatie bediscussieerd.

Hoofdstuk 3 werkt de nieuwe analyse methode verder uit. Deze methode wordt verder in het proefschrift de Event-Related Fixed-Interval Areas (ERFIA) multilevel methode genoemd. Het primaire doel is om te onderzoeken of de ERFIA multilevel methode vergelijkbare resultaten met betrekking tot het pijn ERP oplevert ten opzichte van de conventionele piekanalyses. De ERFIA multilevel methode wordt getest op een bestaande EEG dataset die bestaat uit 84 proefpersonen, die 150 elektrische stimuli kregen toegediend van 5 verschillende intensiteiten. De periode na een stimulus die 1500 ms bedraagt, werd opgedeeld in 75 oppervlaktes van 20 milliseconden. Het hele ERP signaal werd onderzocht door de variantie van opeenvolgende 20-ms 'ERFIAs' te modelleren voor onder andere de volgende factoren: stimulus intensiteit, voorgaande stimulus intensiteit en habituatie. Ten opzichte van piekanalyses, laat de ERFIA multilevel methode vergelijkbare resultaten zien wat betreft de invloed van stimulus intensiteit en habituatie. Daarnaast blijkt dat de invloed van stimulus intensiteit en het fenomeen habituatie zich beiden niet alleen beperken tot pieken maar met een veel groter deel van het ERP signaal verband hebben. Vervolgens werd aangetoond dat de corticale verwerking van de huidige stimulus intensiteit afhankelijk is van de intensiteit van de voorgaande prikkel in een groot deel van het ERP signaal. Deze bevinding impliceert dat het brein een vergelijk maakt van de voorgaande prikkel met de huidige, mogelijk als een soort stimulus geheugen proces.

Hoofdstuk 4 onderzoekt of de corticale verwerking van pijnprikkels verschillen tussen gezonde proefpersonen en individuen met chronische lage rugpijn met betrekking tot intensiteitsverwerking en habituatie. Er worden 3 vormen van habituatie onderzocht, namelijk een lineaire afname, een inverse afname en een kwadratische vorm (parabool). In deze studie werd er geen verschil in verwerking van de verschillende intensiteiten van de toegediende prikkels gevonden tussen gezond en chronische pijn. Echter, er werd aangetoond dat er bij proefpersonen met chronische lage rug pijn minder habituatie optrad voor alle 3 de vormen ten opzichte van de gezonde proefpersonen. Individuen met chronische lage rugpijn lijken op corticaal niveau dus 'minder te wennen' aan een serie pijnlijke prikkels dan gezonden. Habituatie aan pijn kan dus een belangrijke sleutelfactor zijn in het chronisch worden van pijn. Om dit definitief aan te tonen zijn echter longitudinale studies van belang. 
Hoofdstuk 5 bestudeert de relatie tussen pijn hypervigilantie, habituatie en corticale verwerking van pijn in een gezonde individuen. Pijn hypervigilantie wordt gedefinieerd als verhoogde waakzaamheid (vigilantie) toegespitst op pijnlijke sensaties. Pijn hypervigilantie wordt gezien als een van de mechanismen waardoor een hogere pijnintensiteit wordt gerapporteerd. Hypervigilantie kan al bij gezonde mensen aanwezig zijn en zou als predisponerende factor een rol kunnen spelen in het ontstaan van chronische pijn. In dit hoofdstuk werd onderzocht of gezonde hypervigilante personen een andere corticale verwerking van pijn tonen in vergelijking tot niet hypervigilante individuen. Ten tweede werd onderzocht of de habituatie van pijn verschilt tussen hypervigilante en niet-hypervigilante proefpersonen. De resultaten toonden dat pijn hypervigilantie direct verband heeft met het pijn-ERP van 440 tot 580 ms poststimulus, onafhankelijk van gewenning. Daarnaast werd aangetoond dat pijn hypervigilantie effect heeft op de habituatie van pijnlijke prikkels, zowel op de lineaire als ook de kwadratische habituatie. Bij een hoge hypervigilantie score werd de prikkelverwerking na een initiële afname sterker. Deze resultaten wijzen erop dat hypervigilantie, middels een veranderde corticale verwerking, de beleving van pijn zou kunnen beïnvloeden.

Hoofdstuk 6 gaat in op de vraag of de remming in gewenning aan pijn bij chronische pijn verder wordt geremd door hypervigilantie. Dit komt niet naar voren uit het onderzoek. Het blijkt namelijk dat de factoren chronische pijn en hypervigilantie beiden onafhankelijk effect hebben op habituatie, en niet in een synergistisch verband. De associatie van chronische pijn met habituatie werd gezien van 220-260 ms in bijna alle EEG-electroden en van 580 tot 640 ms poststimulus voor de frontale electroden. Pijn hypervigilantie heeft effect op habituatie van 480 tot $820 \mathrm{~ms}$ poststimulus voor de rechts en centraal gelokaliseerde electroden. Toekomstig onderzoek is noodzakelijk om vast te stellen of de invloed van pijn hypervigilantie en chronische pijn op habituatie via verschillende corticale routes loopt.

Hoofdstuk 7 bespreekt de resultaten van de studies in de voorgaande hoofdstukken. De voordelen van de ERFIA multilevel methode ten opzichte van de gangbare analyse technieken worden besproken, maar ook de aspecten die nog verdere ontwikkeling en aanpassing behoeven. Daarnaast worden toekomstige perspectieven voor onderzoek besproken. De ERFIA multilevel methode is een veelbelovende methode om het hele poststimulus periode en specifieke tijd gerelateerde fenomenen zoals habituatie te onderzoeken. Met deze methode werd aangetoond dat invloeden van stimulus intensiteit, habituatie en pijn hypervigilantie in een groot deel van het ERP invloed hadden en niet alleen op pieken. Replicatie van deze bevindingen is echter belangrijk. Daarnaast zal een combinatie van de ERFIA multilevel methode met andere technieken zoals MRI en ESM het inzicht verder kunnen vergroten in de lokalisatie van corticale pijnprocessen, hun tijdseffecten en context. 